\title{
User-Producer Interaction in the Brazilian Oil Industry: The Relationship Between Petrobras and its Suppliers of Wet Christmas Tree
}

\author{
Giovanna Guimarães Gielfi ${ }^{1}$, Newton Müller Pereira ${ }^{2}$, Rogério Gomes ${ }^{3}$,Vinícius Cardoso de Barros \\ Fornari $^{4}$
}

\begin{abstract}
The objective of this work is to analyze the importance of the user-producer interaction for the innovative process of the Brazilian oil industry from the 2000s. To do so, we selected two of the three providers installed in Brazil that produce the set of valves used in the oil wellhead to control its production, set which is called wet Christmas tree (WCT), the Norway's Aker Solutions and the American FMC Technologies. The results of this analysis indicate not only the development of the oil industry in Brazil is marked by a strategy of cooperative innovation, but they also reveal the importance of geographical proximity and direct cooperation, especially between the centers of engineering and research and development of companies. Furthermore, these partnerships are not limited to the adaptation of products to new needs, but they also include the development of new systems.
\end{abstract}

Keywords: innovation; oil industry; Petrobras; user-producer relationship.

\footnotetext{
1,2Department of Science and Technology Policy (DPCT), Institute of Geosciences (IG), University of Campinas (Unicamp), João Pandiá Calógeras St., 5I, POBox 6I 52, Campinas, SP, Brazil, Zip Code 13083-870. Phone: 551935214653.

E-mail: 'giovannagielfi@ige.unicamp.br, ${ }^{2}$ newpe@ige.unicamp.br

3,4 Department of Economics, São Paulo State University (Unesp).Araraquara-Jaú Highway Km 0I, Zip Code I4800-90I,Araraquara, SP,

Brazil. Phone: 55 1633016272. e-mail: 'rogerigomes@uol.com.br, ${ }^{2}$ viniciuscbfornari@yahoo.com.br
} 


\section{Introduction}

The oil industry is important both for its strategic condition, in terms of the energy matrix, and for the strong linkage it has with other branches of the industry in the countries in which it is installed. In Brazil, in addition to having its participation in the industrial structure present a significant growth - the participation of this industry in GDP is over $10 \%$ according to data from the National Organization of the Petroleum Industry (ONIP) -, due to the high levels of investment, the high rate of innovativeness, technological spillovers for the various industries and contributions to the scientific catch-up has contributed to the strengthening of the national system of innovation.

In the Brazilian case, the state company Petrobras presents itself as the major participant in the oil industry and is an international reference in the activity of exploration and production (E\&P) of offshore oil. This position was endorsed by a technological trajectory that shows a clear option for a cooperative technology development strategy - started in the $80 \mathrm{~s}$ with the institutionalization of in-house research and development (R\&D) activity by the Center for Research and Development Leopoldo A. Miguez de Mello (Cenpes) and with the start of the Deep-water System Technological Innovation Program (PROCAP) 1000 - through the interaction with its suppliers of equipment and services, universities and research institutes.

The choice of an interactive strategy in the innovation process, an essential part of the technical and economic success of the company, leads this analysis to the user-supplier interaction during the 2000s. This interaction and the developments arising from them, including as a means of strengthening the equipment industry for the oil industry and technological trainings, reduction of trade deficits in the industry, and technological, economic and social impacts, can serve as a benchmark for other industries.

This study is divided into four sections, besides this introduction. The first section addresses the innovation process from the interaction between companies, distinguished between those who produce (suppliers) and those who incorporate technological innovation (users). This section presents the theoretical basis that guides the analysis of the cases.

The second part comprises the characterization of the productive stages of the oil industry (with emphasis on upstream), its methods and equipment used.Then we approach the technological development of the offshore oil industry, especially the national one, which is illustrated by the Petrobras case, through its technological training programs for the exploration and production of oil and gas offshore. This section also addresses the changes in the institutional context of the industry and the effects generated by them.
The third section presents the methodology used in carrying out this work and the case studies of the interaction between Petrobras and its suppliers of wet Christmas tree: Aker Solutions and FMC Technologies. Here, we describe the performance of these suppliers in the national oil industry and the developments arising from the user-producer interaction. And, finally, we have the final considerations about the study.

\section{Innovative process and the user-producer interaction}

Schumpeter pioneered the study of the importance of technical progress for the economic science. Since then, the evolutionary or Neo-Schumpeterian theory through its various authors (Richard Nelson, Sidney Winter, Giovanni Dosi, Christopher Freeman, Nathan Rosenberg and, specially, Bengt-Åke Lundvall - to mention only those who had a greater influence on the theoretical design of this study) advanced toward a greater understanding of the innovative process, recognizing it as the driving force of economic development.

Lundvall (1988) presents innovation as an interactive process between users and producers, i.e. between those who benefit from innovations and those who provide them. Here we adopt Petrobras as the user company and the suppliers as producers of innovations. This interaction is of paramount importance in the modern industrial society, since a substantial part of the innovative activities occur in units separated from its potential users. Below, we highlight the main propositions of this relationship according to the mentioned author.

The monitoring of the users' activities by producers and the producers' by the users provides strong incentives. From the producers, the efforts to monitor the activities of potential users of innovations are justified because: I) they allow the appropriation of process innovations and/or discourage the possibility of competitive threat from the users; 2 ) product innovations from users may incur (or encourage) new demands for process equipment; 3 ) the knowledge produced through learning-by-using can only be transformed into new products if there is direct contact with users; 4 ) the existence of technological interdependencies and bottlenecks in user units may represent potential markets; 5) they provide a better assessment of capabilities of adoption of new products by users.

In various segments, users require specific information about new products and, therefore, may need to join a producer for analyzing and solving any problems, as for example in the case of production or technology bottlenecks. Thus, it may be crucial detailed knowledge about the product character-

ISSN: 07I 8-2724. (http://www.jotmi.org)

Journal of Technology Management \& Innovation (c) Universidad Alberto Hurtado, Facultad de Economía y Negocios. 
istics, skills and reputation of the producers, which would explain the monitoring of activities of producers of innovations by users.

In addition to monitoring activities, we can highlight direct cooperation and geographic distance between production units and users, which correlate with the technology complexity and changeability. In these conditions, either by the transformation of the learning-by-using on new products, or by the development of new complex and specific technologies, direct cooperation is necessary so that there is a successful outcome, even though technologies related to information and communication and internet can act to minimize the distance.

The geographical distance influences the success of the new developments when they require direct contact, exchange of information, because they are permeated by tacit knowledge, or even in cases of maintenance, repair and adjustments of products. In this sense, the more necessary to the innovation of these attributes, the greater the proximity of user and producing units must be (Lundvall, 1988).

According to Lundvall, a smaller geographical distance between user and producing units favors greater cultural proximity, collaborates with a good flow of qualitative information, which requires communication channels for transmitting information and a code of communication that ensures the effectiveness of this transmission and the decoding of the knowledge. The establishment of these conditions is time consuming, involves learning and costs. However, they facilitate the diffusion of the innovation, where there repairs and improvements to the product, in this case, as the user points.

Relations between users and producers are selective, since they involve uncertainties, being oriented in terms of technical skills, as well as moral character, and they are not guided by prices. Besides acquiring a new product, users are establishing a cooperation with an external producer for a future time period, and therefore a relationship permeated with uncertainties, either because of repairs and improvements in equipment (technology), or the development of new solutions according to the specific technical requirements or perceived opportunities.

Producers, on the other hand, show users the capabilities of their products and their technical expertise. Thus, both sides are exposed to the risks of opportunistic behavior, indirectly through information leakage to competitors or directly if the market is flooded by the cooperator. Mutual trust is presented, therefore, as a key element in these relations (Lundvall, 1988).
The selectivity of interactions involving mutual trust, the time given and the investment dispensed in establishing codes and channels of communication, and the experience gained through interaction, tend to stabilize the relationships between users and producers, and the changes of partnerships will occur only when facing substantial incentives. Thus, the effectiveness of the relationship tends to increase with time. It is also noteworthy that, in the case of new equipment, two companies - the first company to sell it and the first one to use it - have a relevant role, since both assume the innovative role and take a considerable risk for the enterprise (Rosenberg, 1982). This concept is relevant to us in order to understand the importance of the user-producer relationship in the oil industry, especially in Brazil, given the demands for new technologies that allow the exploration of oil in (ultra) deep-water.

\section{The oil industry and its suppliers}

\section{The productive steps of the industry}

The supply chain of the oil industry has as main features: i) high level of systemic complexity, as it incorporates several interdependent technologies and requires extensive knowledge base; ii) technological development in order to adapt to the geophysical conditions of production and the evolution of the characteristics of derivatives; and iii) is intensive in capital and technology of high-risk development and high profitability.

Simply put, the industry can be divided into two steps: upstream - the focus of this research - and downstream. The first one is divided into two stages: exploration and drilling, completion and production, in which there is a high risk and cost of the activity; the second step comprises the activities of transport, refining and distribution.

The exploration phase corresponds to the set of operations or activities designed to assess areas through geophysical and geological studies, aiming at the discovery, identification and delineation of oil or natural gas deposits. Even with the advancement of technology in this stage, it is only possible to be sure of the existence of oil in a reservoir after drilling the well. The main materials, equipment and services used in this production stage are the seismic and large computers. In the drilling, completion and production phase, there is the activity of drilling the well(s) using special land rigs or special ships (drillships), and prepare it (them) for the implementation of equipment for the permanent production of oil, either through "dry" completion systems (technology developed by Shell in the North Sea) or "wet" completion systems (whose technology was developed by Petrobras in the Campos basin). The drilling of wells cost millions of dollars and this operation may take months, being the highest cost in the offshore segment. 
The completion is the stage following the drilling of a well, designed to equip it to produce oil or gas (or inject fluids in the reservoirs), in a safe and economical way throughout its productive life. The types of completions are distinguished by the position of the wellhead and Christmas tree used. Thus, the dry completion is characterized by positioning the wellhead in the platform; the wet completion is characterized by positioning the wellhead on the seabed.

The main materials and equipment used in this production step are the casing tubes, "Christmas trees" - set of valve that controls the production of the oil well -, flexible pipes, turbines and large generators, and compressors, and the major services are the drilling and cementing of wells, the chartering of support vessels and the launching of submerged lines.

In the downstream segment (refining and transportation), there is the transfer of crude oil to the units responsible for the production of derivatives, being the most relevant equipment the large compressors and pumps, steam turbines, furnaces, towers, pressure vessels and supervisory control systems, and among its main services there are the mechanical maintenance and installation of industrial plants, pipelines and storage systems.

\section{The Brazilian offshore oil industry}

The offshore oil industry emerged in the Gulf of Mexico in the 50s and has expanded into the North Sea. In the late '70s, this latter region was the most important region in the offshore exploration and production (E\&P). The success of the new technology spread the offshore production to other countries and regions. The development of this type of E\&P was accompanied by increased depth of water - an important indicator of the technological frontier of this industry. This process required the development of new technologies.

The main technological challenge posed for the industry concerned the development of production systems that were appropriate to the valuation of deposits located in deep-water. In principle, the technology for drilling at great depths has been around since the $60 \mathrm{~s}$ and can reach up to 5,000 meters. The same goes for the technology of submarine geophysical surveys (Furtado, 1996). With the significant increase in oil production in increasingly deeper waters, the technologies related to drilling, completion and production continue to require technological improvements. The main technology bottleneck of oil industry is the installation of extraction, conditioning and transport systems of oil and natural gas, reliable and with a competitive price. Moreover, the technological challenge differs according to the producing region, due to the variation of the physical conditions of the deposits explored.
The evolution of the national oil industry can be assessed through the development of the state company Petrobras. The company was statutory monopolistic of the E\&P activities until 1997, when the industry went through a process of opening up to private capital. Still, the state company remained as the largest player in this sector. It is worth mentioning the role of the Petroleum Law of 1997, to liberalize the sector and concomitantly regulate it through the creation of the ANP - National Petroleum Agency. The ANP aims to regulate, hire and oversee the economic activities in the sector, as well as prepare the notices and promote the bids for the granting of exploration, development and production activities, signing and overseeing the implementation of contracts.

However, at the beginning of its activity, the representative of the national oil industry faced some setbacks. Among the biggest difficulties, there was the lack of a supply chain. Thus, the company's strategy was based on the acquisition of foreign technology and its adaptation to Brazilian specifications, while it sponsored the training of human resources. This latter strategy aimed at two goals: to enable the technical staff to purchase technology and to enhance the operational capability of the equipment in use. With the formation of a center of technicians trained to develop R\&D activities within the company, such activity was institutionalized in 1966 through CENPES. But it is only in the 80 s, with the rapport of CENPES with the operational departments of the company and the dynamic displacement of the axis from downstream to upstream, that we can see great results.

In the early 80s, Petrobras increased its imports of technology and capital goods initiating an in house learning process. It absorbed foreign technology with the assembly of the first permanent marine systems; the technology was acquired from external sources and the basic engineering sector performed the unpacking (Ortiz Neto and Costa, 2007). This strategy tried to reproduce the technologies in use, but the discovery of deep-water reserves in the country required the generation of its own solutions. It was necessary to develop technologies that ensured the exploration and production since they were not available internationally. In 1986, the government launched its Deep-water System Technological Innovation Program (PROCAP 1000), internalizing the development of technologies that enabled E\&P in high depths. The need for such a program came from the lack of E\&P systems which exceeded 300 meters deep and the discovery of huge reserves in the deep-water of the Campos Basin (Freitas, 1999). The technological effort inaugurated by the state company with a view to exploiting the giant deep-water deposits would count on domestic and foreign agents (capital goods industries, universities, oil companies, engineering companies, etc.). This initiative was made possible by seeking greater technical mastery of the 
domestic market in equipment for the upstream (Freitas, 1999). From this stage, the user-producer interaction became narrower.

The PROCAP 1000 program lasted 6 years and undertook 109 projects that were aimed at improving the technical competence of the state company in the activity of exploration and production of oil in water depths up to 1,000 meters, of which approximately $80 \%$ of the projects were focused on the extension of the existing technology, and the remaining $20 \%$ for the development of new technologies.

In 1993, the PROCAP 2000 was launched, due to the relevance of the E\&P activities in deep-water and the success achieved from the PROCAP 1000. According to Freitas (1999), its main objectives were: to enable technical and economical alternatives for the exploitation of deposits in ultradeep regions (I,000 to 3,000 meters); to develop technological innovation projects which would allow the cost reduction of E\&P of oil and gas, compared to conventional systems in underwater deposits. In this second phase of technological training, it is reinforced the strategy of cooperative technological development.

PROCAP 2000 had a budget of US $\$ 750$ million which funded approximately 20 projects. In contrast to its previous phase, now $80 \%$ of these projects were aimed at innovations and only $20 \%$ were focused on the expansion of existing technologies (Ortiz Neto and Costa, 2007).

The difference between the PROCAP's two phases is that, in the first one, radical innovations were not as important, and, in PROCAP 2000, they began to gain more attention. One of the advances that can be perceived in the learning trajectory of the company is related to the lack of technology transfer programs in PROCAP 2000, observing that the company had already absorbed, in the first program, the technology domain it lacked, and become an international reference in relation to technological efforts oriented to the offshore upstream. Briefly, PROCAP 2000 is to some extent an offshoot of PROCAP 1000, and it illustrates the long-term strategy of the company to intensify its activities in E\&P in deep-water (Freitas, 1999).

PROCAP 3000, which began in 2000 and ended in 2006, had as initial budget US\$ 128 million in R\&D, and it was expected the execution of 19 projects. The main goals of the program were: to enable the production of Marlim Leste and Albacore Leste, in the Campos Basin (RJ), and the next phases of Roncador and Marlim Sul; to enable the production at three thousand meters deep; to reduce the investment in the development of production in water depths exceeding one thousand meters; and to help reduce the extraction costs of production fields (Ortiz Neto and Costa, 2007).

The fact that Brazil occupies a prominent position in the evolution of the technological trajectory of the offshore oil industry is because this renewal process goes through a revitalization of the existing technical bases, rather than going through big jumps or discontinuities in technology (as addressed by Furtado, 1996). Thus, in the scenario of oil exploration and production in deep-water, as for example the Brazilian pre-salt, there is not the domain of a specific system yet, but the competition between technological systems which are more or less predominant.

The programs of technological training from Petrobras have a clear strategy of alliances for the innovative development, resulting in positive effects both in terms of sectors and in spillovers arising from it. The higher qualification of the workforce can also be seen as a positive effect on society.

\section{Petrobras from the 2000s: a new purchase policy}

At the end of the 90s, a new institutional model is put in place in the Brazilian oil industry. This change occurs concomitantly to the break of the legal monopoly of the exploration, production, refining and transportation activities, through the Petroleum Law (Law No. 9.478/1997), by Petrobras. The change in the institutional environment led the state company to seek the reduction of costs through its hiring policy, changing the company's strategy of increasing

\begin{tabular}{|l|l|l|l|}
\hline DECADE & DEPTH (METERS) & TECHNOLOGY PROGRAM & MEANS EMPLOYED \\
\hline 1970 & $400 \mathrm{~m}$ & - & $\begin{array}{l}\text { Import and adaptation of existing } \\
\text { technology }\end{array}$ \\
\hline 1980 & UP to I,000 m & PROCAP $1000(1986)$ & $\begin{array}{l}\text { Cooperation with national shipyards, } \\
\text { enhancement of technologies. }\end{array}$ \\
\hline 1990 & $2,000 \mathrm{~m}$ or more & PROCAP 2000 (1993) & $\begin{array}{l}\text { Strengthening of the cooperative strate- } \\
\text { gy, but with a focus on innovation. }\end{array}$ \\
\hline 2000 & More than 3,000 m & PROCAP 3000 (2000) & \\
\hline
\end{tabular}

Table I: Petrobras' technological trajectory Source: Our own elaboration.

ISSN: 07I 8-2724. (http://www.jotmi.org)

Journal of Technology Management \& Innovation (c) Universidad Alberto Hurtado, Facultad de Economía y Negocios. 
the domestic index of the inputs and equipment purchased. The company began using international bids and including foreign suppliers in its registration. Then, the nationalization index, which was $92 \%$ in the early 90 s, dropped to approximately $80 \%$ over the decade (Marzani, 2004). This new competitive environment implies both new customers for local suppliers and greater competition among companies.

Regarding the expansion of Petrobras' relationships with foreign suppliers, we can highlight the following factors: the need for external finance; the reduction in oil prices, reinforcing the need to reduce costs; the opening of the economy which facilitated the import of inputs and equipment; the difficulty of financing from domestic suppliers; and the appreciation of the Real, reducing the competitive advantages, and the implementation of Repetro - customs procedure for the import of equipment.

In short, the end of the 90s represents a shift in the Petrobras' relationship with its suppliers, which stops being "paternalistic", where the state company bore higher transaction costs related to the quality and the extra costs of local production, and is then guided by competition, aiming to lower costs. Thus, the purchase policy of national suppliers was no longer part of the schedule of sectorial policies.

As a result of Petrobras' new purchase model, the commitment of the suppliers with the operational performance of the equipment and with the technical assistance increased. Besides that, the state company redesigned its range of suppliers to work with global players, aiming to meet the deadlines and technical specifications established, and leaving the production fully under the producer responsibility.
In contrast to the positive results, the opening process caused a considerable increase in the importation of equipment and inputs, which allowed an increase in the Petrobras' levels of investment in the decade. However, the internal unfolding decreased, leading the Government and the company to change their stance. Nevertheless, in the mid-2000s, the purchase policy, as well as the industrial policy, became, again, part of the Government's schedule (Furtado, Pereira and Marzani, 2004). This change in strategy converges with the new guidelines of the President Lula government, which desires to increase the nationalization levels.

\section{Methodology}

The study aims to identify technological developments achieved through the interaction between Petrobras and its suppliers, as well as examine the evolution of these relations and their impact on strengthening the industry of supply of equipment for the oil industry.

We sought to analyze the interaction between Petrobras and one of the segments of the capital goods sector, the suppliers for the upstream, called "first line" suppliers, which provide the wet Christmas tree (WCT), whose operating companies have foreign capital. According to the national registry of suppliers from ONIP (National Organization of the Petroleum Industry), there are 3 companies of this type of equipment in Brazil; among them, we selected the following sample: the Norwegian Aker Solutions in Brazil and FMC Technologies, from the U.S.

From the definition of supplier companies, we performed some major steps to accommodate the objective proposed:

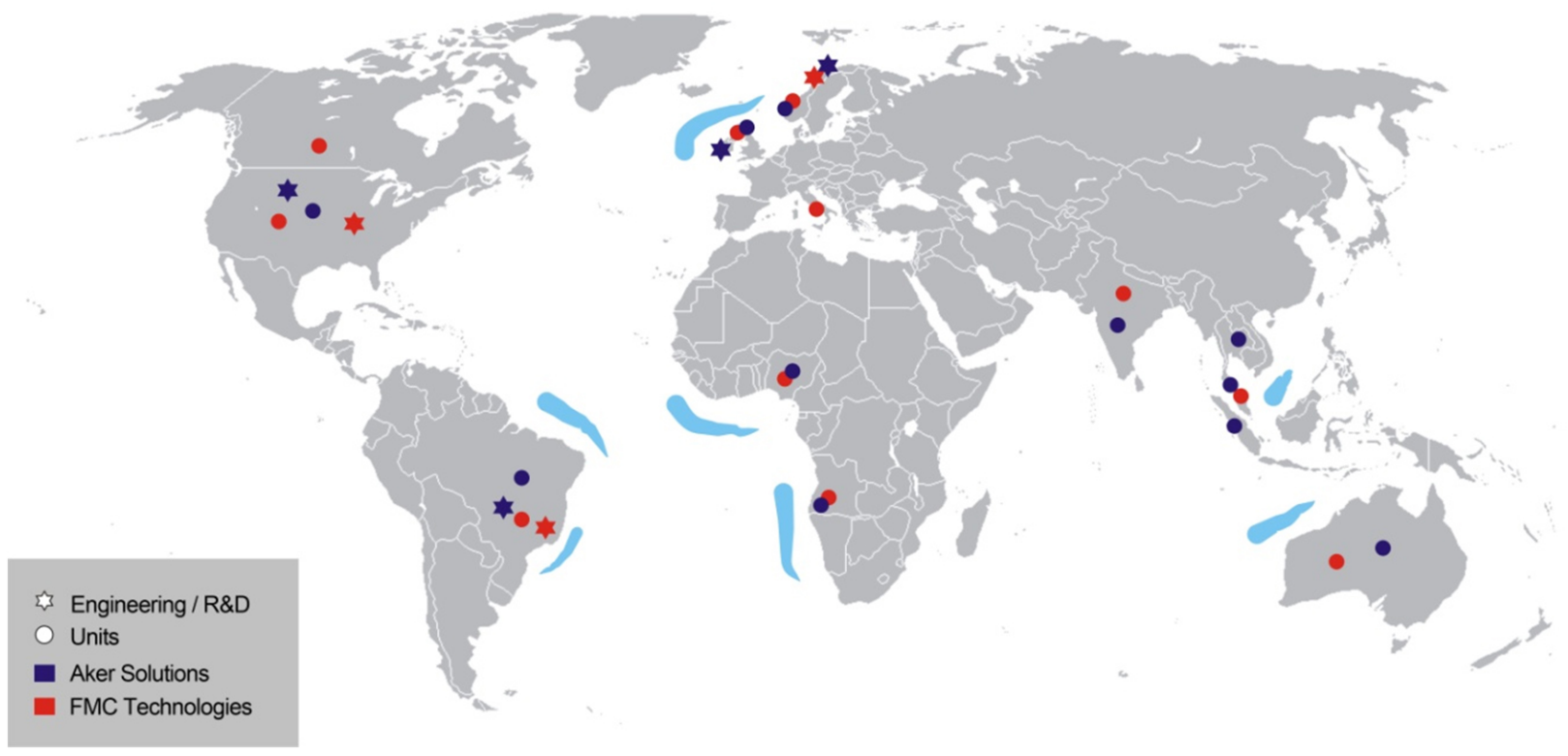

Figure I: Global dispersion of companies from the sample Source: Our own elaboration.

ISSN: 07I 8-2724. (http://www.jotmi.org) 
a) monitoring of the activities of the companies from the sample, through journals, magazines and annual reports; b) preparation of corporate dossiers that meet the highest possible number of qualitative and quantitative information about each company and contextualize them in the industry; c) mapping of the activities of the companies from the sample according to the criteria of geographic region and type of input/activity produced. From this material, the research proceeds through the analysis of "case studies".

\section{The interaction between Petrobras and its suppliers of WCT}

The businesses from the WCT segment installed in the country produce exclusively for the local oil industry, and they have Petrobras as their main client. This fact can be explained by the fact that production to other markets would require adaptation to other technical specifications (physical conditions, such as depth, distance from shore, winds and waves, and geological conditions), generating higher costs to adapt the equipment.

These companies are positioned strategically in countries close to regions that explore and produce offshore oil and gas. Their engineering centers or R\&D laboratories are concentrated in European countries and in the United States, where they have their headquarters. The exception is Brazil, the only country in the Southern Hemisphere where such companies have research and engineering centers. These centers are located in areas near universities and the Petrobras' R\&D center (Cenpes) - for example FMCTechnologies.

\section{The Aker Solutions case}

The company started its activities in 1853 in Oslo, Norway. In the 1960s, the company started to operate in the offshore oil and gas segment, through Kvaerner Engineering in Oslo. The offshore construction activity started in 1978 by then Kvaerner Egersund. Between the end of the 1990s and the end of the first decade of the 2000s the company faced a crisis and merged with its major shareholder,Aker Maritime, adopting a new name, Aker Solutions.

In Brazil, according to the national registry of suppliers from ONIP, Aker Solutions operates in the supply of wet Christmas trees (WCT), risers, actuated valves (gate type) and in the maintenance and repair services of WCTs and others. The group has a factory in Curitiba (State of Paraná-PR), which performs the manufacturing of WCT, one in Rio das Ostras (State of-RJ), which produces drilling risers and serves as the basis of subsea services, and another in the city of Rio de Janeiro (RJ), where it has sales and its engineering center.
It is important to highlight that Aker Solutions strategically positioned its units producing WCT in three countries: Norway (its home country), Brazil and Malaysia. These countries are included in regions where there is the existence of oil reserves in deep-water and whose share of the offshore E\&P is relevant.

The company began its operations in the Brazilian market in 1995 and since then has strengthened and consolidated its activities in this market. Since the beginning of its activity in the country, the company has delivered more than 150 WCTs, besides manifolds, risers and subsea equipment. The group recognizes the importance of a relationship of close proximity to its customers and suppliers and emphasizes its proximity to Petrobras for the development of upstream solutions and technologies, which resulted in the design of several deep-water WCT, such as the WCT Aker Solutions GLL 2000 designed to operate at a depth of 2,000 meters. Throughout the 2000s, the group has developed a range of equipment for Petrobras and in some cases in close cooperation with this company. Below, we highlight the main developments.

During the 2000s, Aker Solutions sought to consolidate its position in the Brazilian market through investments in its plants, expansion of their production capacity and the professional training of its employees; we can emphasize, in 2008 , the construction of the first factory of deep-water drilling risers in Brazil in city of Rio das Ostras (RJ), and the investment in the WCT production unit in Curitiba (PR), with the goal of doubling its production capacity by 2010 . This policy was encouraged by the importance of the country in relation to the offshore E\&P and the growth potential of the industry, due to the discovery of huge oil deposits in the pre-salt layer. The Brazilian policy of national content and the need to be close to the main customer of the industry in Brazil, Petrobras, confirmed the strategy adopted by the company.

The Norwegian group demonstrated stability in its relationship with Petrobras in supplying equipment. The case of development of WCTs for the Brazilian state company during the 2000s shows such stability and it reveals an improvement in the Aker' technological capabilities, observed by the increased depths reached. The same can be said for the other equipment developed; they are: control systems, manifolds, structures, umbilicals, pumping and processing, and platforms. Table 2 summarizes this information.

The interaction between companies is even more interesting in cases of major advances in technology. We can highlight the umbilical case for the Petrobras' project Cascade \& Chinook, in the Gulf of Mexico, which replaced the reinforced steel with carbon fibers in power umbilicals, enabling

ISSN: 07 I8-2724. (http://www.jotmi.org) 
the production at greater depths by reducing weight and tension, and it also provided a patent to the company. In addition, there are the cases of technological developments of WCTs and control systems able to act in the pre-salt layer, which exceeds the 2,500 meters water depth.

The geographical proximity between the companies is seen as a crucial factor in the development of new technologies and enhancements by Aker Solutions. Its performance in Brazil demonstrates this view, since the company has expanded its investment with the construction of the first plant for the production of drilling risers in the country and increased the production capacity of its plant in Curitiba. Additionally, the only engineering center that the group has in the southern hemisphere is located in the Brazil, thus confirming the importance of the Brazilian market for the company.

\section{The FMC Technologies case}

The FMCTechnologies story begins in 1884, when John Bean developed a spray pump for pests in plantations of orange in California. Over time, the company has been diversifying its activities to other sectors, such as: food processing equipment in the 20 s, arms industry, producing amphibian tractors and tanks, under the influence of World War 2, and the chemical and oil equipment sectors after the war. In the 2000 s, the group was restructured and split into two independent parts: FMC Technologies was responsible for the machinery and equipment area, while the FMC Corporation assumed the chemical segment.

In Brazil, according to the national registry of suppliers from ONIP, FMC provides drills for well drilling, Christmas tree (wet and dry), risers, manifolds and metal connections, valves (ball and gate), among other equipment. The company has production units in the cities of Macae (RJ) and Rio de Janeiro (its headquarters). In 2010, FMC Technologies announced the construction of a technology center in Rio de Janeiro, on Ilha do Fundão, near Cenpes (Petrobras' R\&D center) and the Federal University of Rio de Janeiro (UFRJ). This is the third technology center of the company in the world. The other two are located in Norway and in the United States

FMC Technologies provides equipment and services to the domestic oil industry since 196I, through its Brazilian subsidiary, FMC CBV Subsea. The company's activities

\begin{tabular}{|c|c|c|c|c|c|c|c|c|c|c|}
\hline & $\begin{array}{l}\text { Wet Christmas } \\
\text { Tree (WTC) }\end{array}$ & & & & & & & & & \\
\hline Year & 2001 & 2001 & 2002 & 2003 & 2003 & 2003 & 2006 & 2008 & 2009 & 2010 \\
\hline Projects & Albacora & $\begin{array}{l}\text { Albacora } \\
\text { Leste }\end{array}$ & Bicudo & $\begin{array}{l}\text { Bonito, Bicudo } \\
\text { and Albacora }\end{array}$ & Marlim Sul & Jubarte & $\begin{array}{l}\text { Peroá } \\
\text { (phase 2) }\end{array}$ & $\begin{array}{l}3 \text {-year } \\
\text { contract }\end{array}$ & Tupi & Lara e Guará \\
\hline Location & Brazil & Brazil & Brazil & Brazil & Brazil & Brazil & Brazil & Brazil & $\begin{array}{l}\text { Santos } \\
\text { Basin }\end{array}$ & $\begin{array}{l}\text { Brazil (pre- } \\
\text { salt) }\end{array}$ \\
\hline Amount & 5 & 12 & 4 & 2 & 15 & 2 & 3 & 45 & 9 & 40 \\
\hline \multirow[t]{2}{*}{$\begin{array}{l}\text { Depth } \\
\text { (meters) }\end{array}$} & 2,000 & 2,000 & 300 & 300 & 2,000 & 2,000 & 250 & several & 2,500 & 2,500 \\
\hline & $\begin{array}{l}\text { Control, } \\
\text { Processing } \\
\text { and Pumping } \\
\text { Systems }\end{array}$ & & $\begin{array}{l}\text { Manifolds, } \\
\text { Structures e } \\
\text { Umbilicals }\end{array}$ & & & & & & & \\
\hline Year & 2000 & 2007 & 2009 & 2010 & & 2007 & 2007 & 2007 & 2007 & 2008 \\
\hline Projects & SBMS & $\begin{array}{l}\text { Jubarte } \\
\text { (phase 2) }\end{array}$ & & $\begin{array}{l}\text { Lara and } \\
\text { Guará }\end{array}$ & & $\begin{array}{l}\text { Albacora } \\
\text { RWI }\end{array}$ & $\begin{array}{l}\text { Jubarte } \\
\text { (phase 2) }\end{array}$ & $\begin{array}{l}\text { Plem Sul } \\
\text { Capixaba }\end{array}$ & $\begin{array}{l}\text { Manifold } \\
\text { Albacora }\end{array}$ & $\begin{array}{l}\text { Petrobras' } \\
\text { Cascade \& } \\
\text { Chinook }\end{array}$ \\
\hline Location & Brazil & Brazil & Brazil & $\begin{array}{l}\text { Brazil (pre- } \\
\text { salt) }\end{array}$ & & $\begin{array}{l}\text { Campos } \\
\text { Basin }\end{array}$ & $\begin{array}{l}\text { Campos } \\
\text { Basin }\end{array}$ & Brazil & Brazil & Gulf of Mexico \\
\hline Amount & 1 & $\begin{array}{l}8 \text { pumping } \\
\text { system }\end{array}$ & $\begin{array}{l}8 \text { pumping } \\
\text { system } \\
\text { (Moho) and } \\
\text { emergency } \\
\text { valve }\end{array}$ & 17 & & 2 & 1 & 1 & 2 & $65 \mathrm{~km}$ \\
\hline $\begin{array}{l}\text { Depth } \\
\text { (meters) }\end{array}$ & 500 & - & - & 2,500 & & $>2,000$ & $>2,000$ & 1,193 & 1,000 & 2,700 \\
\hline
\end{tabular}

Table 2:Aker Solutions' developments for Petrobras Source: Our own elaboration.

ISSN: 07 I8-2724. (http://www.jotmi.org)

Journal of Technology Management \& Innovation (c) Universidad Alberto Hurtado, Facultad de Economía y Negocios. 
in Brazil include local engineering, project management, manufacturing, integration testing, installation and customer support. Throughout the 2000 s, the company developed together with Petrobras technologies that enable oil E\&P in deep-water.

As we can see in Table 3, FMC Technologies had, over the 2000s, a continuous and stable relationship in the development of equipment to Petrobras. Along with this stability there is a technological breakthrough in projects, which are capable of operating at increasing depths and under conditions of elevated temperatures and pressures $(\mathrm{HP} / \mathrm{HT})$. This stability of the interaction between companies is beneficial and helps reduce the uncertainties of the innovative process (Lundvall, 1988).
FMC through the building of its technology center in Rio de Janeiro demonstrates the importance given by the company to the national oil industry, in particular its relationship with Petrobras. The proximity between the companies' centers of technology reduces cultural barriers and tends to facilitate greater interaction between them (Lundvall, 1988).

It is worth highlighting the positive results of the interaction between companies for the development of new technologies and viability of the offshore E\&P in (ultra) deep-water, such as the separation system developed for the Marlim field and equipment that operate under high pressure and temperature $(\mathrm{HP} / \mathrm{HT})$.

\begin{tabular}{|c|c|c|c|c|c|c|c|c|c|c|c|c|}
\hline & $\begin{array}{l}\text { Wet Christ- } \\
\text { mas Tree } \\
\text { (WTC) }\end{array}$ & & $\begin{array}{l}\text { Pro- } \\
\text { cessing } \\
\text { and } \\
\text { Pump- } \\
\text { ing }\end{array}$ & & & & & & & & & \\
\hline Year & 2001 & 2002 & 2002 & 2005 & 2005 & 2006 & 2006 & 2007 & 2008 & & 2007 & 2009 \\
\hline Projects & $\begin{array}{l}\text { Albacora } \\
\text { Leste }\end{array}$ & \begin{tabular}{|l} 
Ronca- \\
dor and \\
Alba- \\
cora \\
Leste
\end{tabular} & $\begin{array}{l}\text { Campos } \\
\text { Basin }\end{array}$ & $\begin{array}{l}\text { Golfin- } \\
\text { ho and } \\
\text { Pirane- } \\
\text { ma }\end{array}$ & $\begin{array}{l}\text { Cotton- } \\
\text { wood }\end{array}$ & $\begin{array}{l}3 \text {-year } \\
\text { contract }\end{array}$ & Mexilhão & $\begin{array}{l}\text { Petrobras' } \\
\text { Cascade \& } \\
\text { Chinook }\end{array}$ & $\begin{array}{l}\text { Ronca- } \\
\text { dor }\end{array}$ & & $\begin{array}{l}\text { Petrobras' } \\
\text { Cascade \& } \\
\text { Chinook }\end{array}$ & Marlim \\
\hline Location & Brazil & Brazil & Brazil & Brazil & \begin{tabular}{|l} 
Gulf of \\
Mexico \\
\end{tabular} & Brazil & Brazil & $\begin{array}{l}\text { Gulf of } \\
\text { Mexico }\end{array}$ & Brazil & & $\begin{array}{l}\text { Gulf of } \\
\text { Mexico }\end{array}$ & Brazil \\
\hline Amount & 2 & 11 & - & 13 & 2 & 30 & $\begin{array}{l}6(\mathrm{HP} / \\
\mathrm{HT})\end{array}$ & 4 & 11 & & $\begin{array}{l}2 \text { pumping } \\
\text { systems }\end{array}$ & $\begin{array}{l}1 \text { separation } \\
\text { system }\end{array}$ \\
\hline \multirow[t]{2}{*}{$\begin{array}{l}\begin{array}{l}\text { Depth } \\
\text { (meters) }\end{array}\end{array}$} & - & 2,000 & 1,500 & 2,000 & 2,000 & 2,000 & - & $>2,000$ & - & & 2,600 & 900 \\
\hline & $\begin{array}{l}\text { Manifolds, } \\
\text { Risers, } \\
\text { Control } \\
\text { Systems and } \\
\text { Umbilicals } \\
\end{array}$ & & & & & & & & & & & \\
\hline Year & 2001 & 2001 & 2002 & 2002 & 2004 & 2006 & 2007 & 2007 & 2008 & 2009 & & \\
\hline Projects & $\begin{array}{l}\text { Albacora } \\
\text { Leste }\end{array}$ & $\begin{array}{l}\text { Alba- } \\
\text { cora } \\
\text { Leste }\end{array}$ & $\begin{array}{l}\text { Campos } \\
\text { Basin }\end{array}$ & $\begin{array}{l}\text { Ronca- } \\
\text { dor }\end{array}$ & Roncador & Mexilhão & $\begin{array}{l}\text { Petrobras' } \\
\text { Cascade } \\
\& \text { Chi- } \\
\text { nook }\end{array}$ & $\begin{array}{l}\text { Roncador, } \\
\text { Albacora } \\
\text { Leste and } \\
\text { Campos } \\
\text { Basin }\end{array}$ & $\begin{array}{l}\text { Ronca- } \\
\text { dor }\end{array}$ & $\begin{array}{l}\begin{array}{l}\text { Ron- } \\
\text { cador } \\
\text { (module }\end{array} \\
3 \text { ) }\end{array}$ & & \\
\hline Location & Brazil & Brazil & Brazil & Brazil & Brazil & Brazil & $\begin{array}{l}\text { Gulf of } \\
\text { Mexico }\end{array}$ & Brazil & Brazil & Brazil & & \\
\hline Amount & 3 manifolds & $\begin{array}{l}2 \\
\text { control } \\
\text { systems }\end{array}$ & $\begin{array}{l}5,500 \\
\mathrm{~m} \text { of } \\
\text { risers }\end{array}$ & $\begin{array}{l}1 \text { mani- } \\
\text { folds }\end{array}$ & $\begin{array}{l}\text { control } \\
\text { system }\end{array}$ & $\begin{array}{l}2 \mathrm{HP} / \mathrm{HT} \\
\text { mani- } \\
\text { folds }\end{array}$ & $\begin{array}{l}3 \text { mani- } \\
\text { folds }\end{array}$ & 2 manifolds & $\begin{array}{l}11 \\
\text { PLETs } \\
\text { and } 11 \\
\text { jump- } \\
\text { ers }\end{array}$ & $\begin{array}{l}4 \text { man- } \\
\text { ifolds } \\
\text { and } \\
\text { controls }\end{array}$ & & \\
\hline $\begin{array}{l}\begin{array}{l}\text { Depth } \\
\text { (meters) }\end{array} \\
\end{array}$ & - & - & - & 1,892 & - & - & $>2,000$ & - & - & - & & \\
\hline
\end{tabular}

Table 3: FMC Technologies' developments for Petrobras Source: Our own elaboration.

ISSN: 07 I8-2724. (http://www.jotmi.org)

Journal of Technology Management \& Innovation (C) Universidad Alberto Hurtado, Facultad de Economía y Negocios. 


\section{Final Considerations}

This study examined the relationship between Petrobras and its suppliers of wet Christmas tree (WCTs) over the 2000 s, using the concept of user-producer interaction, in which the innovations result from the interactive process between those who use them, called users (Petrobras), and those who provide them, producers (FMC Technologies and Aker Solutions).

The intensity of the relationship addressed is due to the characteristics of the activity of oil exploration and production in deep-water: high systemic complexity, large technological dynamism and intensity of capital and technology. The need to differentiate the equipment according to the well to be explored is justified by the internal logic of the activity, since the technologies are subject to the physical and geophysical conditions of the deposit.

Another positive aspect of the close relationship between Petrobras and its suppliers of WCT concerns the certainty that the technology under development will meet the demands of the user, increasing its chances of future commercial gain.

In the cases of interaction studied, we can see important technological developments that can be demonstrated by the increasing depths reached by the equipment. The WCTs had a $25 \%$ increase in the depth supported throughout the 2000 s. Depth is an important indicator of the technological frontier of this industry and its increase implies the need for improvements and adaptations of materials, equipment and services employees, as the physical conditions (temperature, pressure, distance from the coast, winds, waves, etc.) of hydrocarbon reserves are changed.

Aker Solutions is the only company with contracts for the supply of WCTs for the pre-salt layer; only in 2010, 57 of these equipment were ordered. We emphasize that the company strategically positioned its units producing WCTs in two countries besides its headquarters (Norway), Malaysia and Brazil, and, in the latter, the group made investments to double the production capacity.

The umbilicals developed for the Petrobras' project Cascade \& Chinook in 2008 were of great importance for the advancement of technical improvements of the equipment, through the replacement of traditional materials. This venture led to a patent for Aker Solutions.

Among the technological advances observed, we can highlight the first subsea oil and gas separation system in deepwater which will act in water depths of 900 meters, produced by FMC for Petrobras. For the interaction of these companies, this kind of development is important, because of the innovative role assumed and the risk undertaken. In addition, it illustrates the complexity and importance of the user-producer relationship in the oil industry, especially in Brazil, given the demands of new technologies that allow the exploration and production of oil in (ultra) deep-water. In the case of FMC Technologies, we can also observe Petrobras ordering a technical solution. This consists of the manifolds for the Roncador field in 2002, which consisted of a installation record for the time. Also, their equipment is able to act in conditions of high pressures and depths - technology named by the company as HP/HT.

The geographical proximity between companies, especially their research centers, proved to be a major factor in the innovation process by fostering greater cultural proximity, facilitating the exchange of knowledge and enabling the transformation of learning-by-using in innovations. As we have seen, Brazil is the only country in the Southern Hemisphere where both companies have technology centers. Among other factors that reinforced the importance of geographical proximity between companies, we have: the ability of suppliers to reduce adjustment costs from the technical specifications of the equipment and the more effective monitoring and adapting to demand.

The continuous and stable relationships between companies, predating the 2000 s, help reduce uncertainties that exist in the cooperation and provide improvements of the technological capabilities. In this sense, the relationships become more effective. 


\section{References}

DANTAS, A.T. Capacitação tecnológica de fornecedores em redes de firmas: o caso da indústria do petróleo offshore no Brasil.Tese de Doutorado. IE/UFRJ. Rio de Janeiro, 1999.

FREITAS,A. G. Processo de aprendizagem da Petrobrás: programas de capacitação tecnológica em sistemas de produção offshore. Tese de Doutorado. Faculdade de Engenharia Mecânica. UNICAMP. Campinas, 1999.

FURTADO, A. T. A trajetória tecnológica da Petrobrás na produção offshore. Revista Espacios Digital, v. 17 (3), 1996

FURTADO, A. T. PEREIRA, N. M. E MARZANI, B. A política de compras da Petrobras: a nova relação contratual. $X$ Congresso Brasileiro de Energia - CBE, Projetos Estruturantes de Energia no Brasil, pp. I 729- 1744, 2004.

LUNDVALL, B. Innovation as an interactive process: from user-producer interaction to the national system of innovation. In: DOSI et alli,Technical Change and Economic Theory, London, Printer Publishers, 1988

MARZANI, B. S. Avaliação de competências dos fornecedores locais da indústria de petróleo e gás natural. Dissertação de Mestrado, DPCT/IGE UNICAMP. Campinas, 2004.

ORTIZ NETO, J. B., e COSTA, A. J. D. A Petrobrás e a exploração de Petróleo Offshore no Brasil: um approach evolucionário. Revista Brasileira de Economia, v. 6I n. I / p. 95-109, Jan-Mar 2007.

ROSENBERG, N. On Technological Expectations. In: Inside the Black Box: technology and economics, cap. 5, pp. I04-I I9, Cambridge: Cambridge University Press, 1982.

SCHUMPETER, J. Capitalism, Socialism and Democracy. Routledge, 1942. 